\title{
Experimental low-temperature physics
}




\section{Series advisers}

Physics titles: $\quad$ Dr R L Havill, University of Sheffield

Dr A K Walton, University of Sheffield

Chemistry titles: Dr D M Adams, University of Leicester

Dr M Green, University of York

\section{Titles in the series}

Group Theory for Chemists, G Davidson

Thermal Physics, $M$ Sprackling

Lanthanides and Actinides, S Cotton 


\section{MACMILLAN PHYSICAL SCIENCE SERIES}

\section{Experimental low- temperature physics}

Anthony Kent

Dept of Physics, University of Nottingham 
All rights reserved. No reproduction, copy or transmission of this publication may be made without permission.

No paragraph of this publication may be reproduced, copied or transmitted save with written permission or in accordance with the provisions of the Copyright, Designs and Patents Act 1988 , or under the terms of any licence permitting limited copying issued by the Copyright Licensing Agency, 90 Tottenham Court Road, London W1P 9HE.

Any person who does any unauthorised act in relation to this publication may be liable to criminal prosecution and civil claims for damages.

First published 1993 by THE MACMILLAN PRESS LTD

Houndmills, Basingstoke, Hampshire RG21 2XS

and London

Companies and representatives

throughout the world

ISBN 978-0-333-51951-6

ISBN 978-1-349-22736-5 (eBook)

DOI 10.1007/978-1-349-22736-5

A catalogue record for this book is available from the British Library 


\section{Contents}

$\begin{array}{ll}\text { Preface ix } & \text { ix }\end{array}$

Chapter 1 Introduction 1

1.1 The concept of temperature 1

1.2 The laws of thermodynamics 4

$\begin{array}{lll}1.3 & \text { Order and disorder and low temperatures } & 7\end{array}$

1.4 A brief history of low-temperature physics 9

1.5 Applications of low temperatures 10 Bibliography 11

Chapter 2 Properties of solids at low temperatures 12

$\begin{array}{lll}2.1 & \text { General properties } & 12\end{array}$

2.2 Electronic properties of materials at low temperatures 24

2.3 Superconductivity 37

Bibliography 51

Chapter 3 Properties of liquid helium 52

3.1 Liquid ${ }^{4} \mathrm{He} \quad 52$

3.2 Liquid ${ }^{3} \mathrm{He} \quad 62$

3.3 Liquid ${ }^{3} \mathrm{He}-{ }^{4} \mathrm{He}$ mixtures $\quad 70$

$\begin{array}{lll}3.4 & \text { Solid helium } & 72\end{array}$

3.5 Adsorbed helium films $\quad 73$

Bibliography $\quad 74$ 


\section{Chapter 4 Reaching low temperatures, stage 1:} ${ }^{4} \mathrm{He}$ cryogenic systems $300-1 \mathrm{~K}$

4.1 Liquid cryogens

4.2 Liquefaction of gases $\quad 77$

4.3 Storage and handling of liquid cryogens 91

4.4 Low-temperature experimental apparatus 94

4.5 Obtaining temperatures above $4.2 \mathrm{~K} \quad 99$

4.6 Obtaining temperatures below $4.2 \mathrm{~K} \quad 103$

4.7 Thermal contact and Kapitza resistance 107 Bibliography

Chapter 5 Reaching low temperatures, stage 2: ${ }^{3} \mathrm{He}$ and ${ }^{3} \mathrm{He}{ }^{4} \mathrm{He}$ cryogenic systems, $1 \mathrm{~K}-1 \mathrm{mK}$

5.1 The ${ }^{3} \mathrm{He}$ cryostat

5.2 The ${ }^{3} \mathrm{He}-{ }^{4} \mathrm{He}$ dilution refrigerator 113

5.3 Pomerantchuk cooling 119

5.4 Working at millikelvin temperatures 123 Bibliography

Chapter 6 Reaching low temperatures, stage 3: adiabatic demagnetization, $1 \mathrm{mK}$ -

6.1 Magnetic properties of matter at low temperatures 125

6.2 Magnetic work

6.3 Entropy in magnetic sub-systems

6.4 Principles of magnetic cooling

6.5 Practical magnetic cooling

6.6 Working at microkelvin temperatures

Bibliography

7.1 Thermometry between $1 \mathrm{~K}$ and room temperature 149

7.2 Thermometry below $1 \mathrm{~K}$

7.3 Temperature measurement in the presence of magnetic fields

Bibliography 
Chapter 8 Experimental techniques

8.1 Vacuum technique 177

8.2 Electrical wiring at low temperatures 188

8.3 Optical access 194

8.4 Mechanical access 196

8.5 High magnetic fields and low temperatures 197 Bibliography 202

Appendix: Laser cooling $\quad 203$

References 208

$\begin{array}{ll}\text { Index } & 209\end{array}$ 


\section{Preface}

Many university physics departments now offer a short series of lectures on low-temperature physics. Usually these are given as a final-year option, or as part of a course on thermal physics. Low-temperature physics pulls together strands from a number of essential core subjects: thermodynamics and statistical physics, quantum physics and solid-state physics. It also provides an interesting framework in which to illustrate and expand on the theoretical concepts taught in previous years. Applications of low temperatures are becoming widespread in research and industry, and a basic grounding in the subject is considered desirable for all serious students of science and technology.

This textbook fills the need for an uncomplicated introduction to experimental aspects of low-temperature physics, concentrating on the methods used to achieve low temperatures in the laboratory. I have avoided the detailed theoretical treatments found in other books, which are primarily aimed at researchers in the subject. Some basic experimental techniques are covered, but at a level that might be of use to an undergraduate project student or a first-year research student using, rather than researching into, low-temperature techniques. I have included theory only where it is essential to illustrate the point being made and without using mathematics or introducing concepts that the average third-year undergraduate student will not have met before.

In Chapters 2 and 3, I review some of the basic physical properties of matter at low temperatures. Detailed theoretical explanations of the properties are not given, because these may be found in other standard textbooks on thermal and solid-state physics. Instead, I pay particular attention to those properties that are relevant to the material of later chapters. In Chapters 4 , 5 and $6 \mathrm{I}$ describe the methods that are used to attain low temperatures in the laboratory, starting from around $300 \mathrm{~K}$ and ending at less than a microkelvin. Thermometry goes hand in hand with being able to attain low temperatures. In Chapter 7, I describe the methods, both primary and secondary, used to measure low temperatures. Finally, Chapter 8 contains a few 'hints and tips' for the would-be low-temperature experimenter. 
I am grateful to the following for granting me permission to reproduce copyrighted figures: J. G. M. Armitage, University of St. Andrews (Figure 3.5(b)); Oxford University Press (Figures 3.10-3.12); McGraw-Hill (Figure 4.5); Oxford Instruments Ltd (Figures 7.8-7.10); Cambridge University Press (Figures 5.7, 5.8 and 7.15(c); Academic Press (Table 7.2); and Linde Cryogenics Ltd (Figure 4.2).

Every effort has been made to trace all copyright holders, but if any have been inadvertently overlooked, the publishers will be pleased to make the necessary arrangements at the first opportunity.

Nottingham, 1992

AJK 